\title{
ICE-THICKNESS MAP OF THE WEST ANTARCTIC ICE STREAMS BY RADAR SOUNDING
}

\author{
by \\ S. Shabtaie and C.R. Bentley
}

(University of Wisconsin-Madison, Geophysical and Polar Research Center, 1215 W. Dayton Street, Madison, WI 53706-1692, U.S.A.)

\section{ABSTRACT}

Extensive radar ice-thickness sounding of ice streams $\mathrm{A}, \mathrm{B}$, and $\mathrm{C}$, and the ridges between them, has been carried out. Closely spaced flight lines, as well as ties to numerous ground stations, have enabled us to compile a detailed ice-thickness map of the area. The map reveals a highly complex pattern of ice-thickness variations, which, because they are much larger than the surface relief, largely reflect the subglacial topography. Several cross-sectional profiles across the ice streams and ridges are shown, and a new configuration for Ice Stream A is presented.

Ice Stream $\mathrm{A}$ is connected to Reedy Glacier and Horlick Ice Stream by subglacial troughs that converge down-stream. The single trough continues, at a depth of more than $1000 \mathrm{~m}$ below sea-level, beneath the entire length of the ice stream and adjacent part of Ross Ice Shelf. Ridge $\mathrm{AB}$ (part of which may be a remanent ice stream) overlies a deep bed with pronounced troughs at its headward end; the bed shoals rapidly down-stream to a height more than $500 \mathrm{~m}$ above the beds of the adjacent ice streams. Ice stream BI overlies a subglacial trough that is deep inland and also shoals markedly toward the grounding line. Near its head, Ice Stream B2 is as much as $1000 \mathrm{~m}$ thinner than Ice Stream B1, but then remains much more nearly constant in thickness along its length. Ridge BC is characterized by a smoother bed and less variation in bed depth than ridge $\mathrm{AB}$. Ice Stream $\mathrm{C}$, which is inactive, is particularly marked by uncorrelated maxima and minima in surface and bed topography.

There are no distinct topographical steps that demarcate the transition from sheet to streaming flow at the head of the ice streams, and the ice streams are placed asymmetrically in some places with respect to their subglacial troughs. This may reflect a relative impermanence or transient behavior of the "Ross" ice streams.

\section{INTRODUCTION}

Radar soundings over West Antarctica in the late 1960s (Robin and others 1970, Robin 1975) revealed the existence of the "Ross" ice streams. Based on data collected from those flights and on surface elevations obtained during IGY West Antarctic traverses, Hughes (1973) prepared the sketch map of these ice streams. Following the airborne radar-sounding program of NSF-SPRI-TUD over West Antarctica during $1974-75$ and 1977-79, a much more detailed map of the ice streams of West Antarctica was produced (Rose 1979). An ice-thickness map of the area compiled at a $500 \mathrm{~m}$ contour interval by Drewry (1983) revealed the broad features of the thickness of the West Antarctic ice sheet.

The "Ross" ice streams are responsible for most of the drainage of the West Antarctic ice sheet into Ross Ice Shelf, yet their dynamic behavior is poorly understood. In order to learn more about these ice streams, radar-sounding techniques have been used to investigate the physical nature of the ice streams and much of the region around them.
The data were collected during the 1984-85 austral summer along the flight lines shown in Figure 1, as part of the Glaciogeophysical Survey of the Interior Ross Embayment (GSIRE). About $18000 \mathrm{~km}$ of flight lines were completed, covering ice streams $\mathrm{A}, \mathrm{B}$, and $\mathrm{C}$, the ridges and domes between the ice streams, the grounding zone between Ross Ice Shelf and West Antarctica, and Crary Ice Rise. Recent results from this program (Shabtaie and Bentley 1987) give new locations for the boundaries of ice streams A, B, and $\mathrm{C}$, including their respective grounding lines, and for the ice rises on the adjoining Ross Ice Shelf. It was discovered that the grounding line of ice streams A and B extends far beyond the previously mapped position, and that the ice streams end in a transition zone ("ice plain") before the grounding line is reached. On this ice plain, the mean surface slope is only $3.5 \times 10^{-4}$ (Shabtaie and others 1987) and the surface elevations are only a few tens of meters above the hydrostatically equilibrated surface (Shabtaie and Bentley 1987). In this study we report on ice-thickness patterns of ice streams $\mathrm{A}, \mathrm{B}$, and $\mathrm{C}$, and their environs. A new configuration for Ice Stream A (now A1 and A2) is also presented.

INSTRUMENTATION, NAVIGATION, AND GEODETIC CONTROL

Our instrumentation and techniques have been described previously in some detail (Shabtaie and Bentley 1987), so we present only a brief summary here. Radar sounding was carried out using a $35 \mathrm{MHz}$ SPRI Mark II pulse-modulated radar, mounted on a DeHavilland Twin Otter aircraft. The recording system consisted of a Honeywell Visicorder and its matching thermal-intensifier camera. Folded dipole antennas in rigid housings were suspended under the wings of the Twin Otter.

Inertial navigation was used, with ties to many surface stations, where positions were accurately measured. This tight navigational control provided the accurate positioning of flight lines necessary for detailed correlation of relatively small changes in ice thickness between flight lines. The positions of the ground-control stations (Bindschadler and others 1987b, Shabtaie and Bentley 1987, Whillans and others 1987) were obtained from data collected by Magnavox MX1502 Transit satellite receivers, with standard errors of no more than about $20 \mathrm{~m}$.

\section{DATA REDUCTION}

The aircraft was flown at a constant pressure elevation, at heights that varied from flight to flight between 300 and $2000 \mathrm{~m}$. The reflection time was obtained from the record, with an accuracy of better than $0.05 \mu \mathrm{s}(\sim 4 \mathrm{~m})$ at intervals of roughly $1 \mathrm{~km}$, and a constant velocity of $171 \mathrm{~m} / \mu \mathrm{s}$ was used for computing the ice thicknesses. The combined error of velocity and digitization is about $1 \%$ of the total ice thickness. The effect of navigational errors is more important in some places. The raw misclosure error in a 


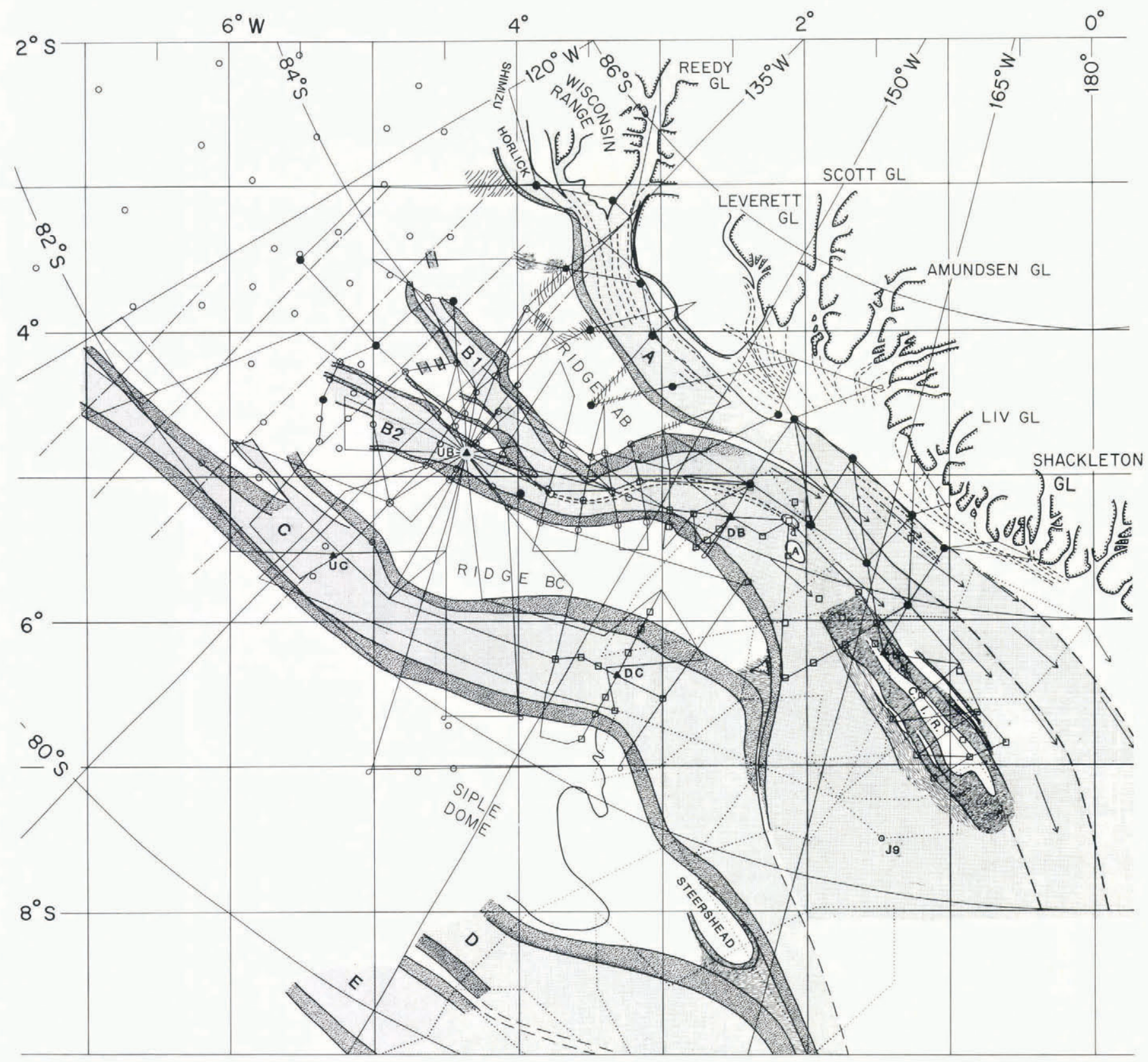

Fig. 1. Map of the West Antarctic ice streams A, B, and C, and their associated flow bands on Ross Ice Shelf (from Shabtaie and Bentley 1987). The 1984-85 radar flight lines (solid) and selected RIGGS (1973-78) flight lines (dotted) are shown. The dashed-dotted lines are sections of the 1974-75 NSF-SPRI-TUD radar-sounding program (Rose 1979) that have been used for the ice-thickness map. Heavy shading marks the marginal shear zone (active or relict) of the ice streams; the light shading is the relatively less chaotic part of the ice streams and their flow bands. The dashed lines in Ice Stream A and in the grid north-western corner of the ice shelf are flow lines; the dashed lines between ice streams B1 and B2 mark the central suture zone. Inferred margins between ice-stream flow bands on the ice shelf are shown by long dashed lines. The base camps (UB, DB, UC, DC, and CR) are shown by triangles. The ice rises are shown by a solid line and no shading inside. C.I.R. is Crary Ice Rise. The shading around the ice rises shows heavily crevassed marginal areas. Surface stations are denoted by: solid circles, University of Wisconsin stations; open circles, Ohio State University and OSU-NASA co-operative stations (Whillans and others 1987); and squares, University of Chicago-NASA stations (Bindschadler and others 1987a). The origin of the rectangular grid coordinate system used on this and succeeding maps is at the South Pole; grid north is toward Greenwich and therefore toward the top of the map. Squares are $1^{\circ}$ of latitude $(111 \mathrm{~km})$ on a side.

flight loop totalling $1000 \mathrm{~km}$ averages about $5 \mathrm{~km}$. However, the ties to known position along the route allowed the mean positional accuracy to be improved to better than $1 \mathrm{~km}$ along the flight lines. The resulting error in the ice thickness is directly proportional to the ice-thickness gradient; near the grounding lines and at the down-stream end of the ice stream, the ice-thickness gradient of $5 \times 10^{-3}$ yields an error in ice thickness of only $\pm 5 \mathrm{~m}$. For the up-stream part of ice streams, however, the gradient increases to a value of about $5 \times 10^{-2}$, which results in an ice-thickness error of $\pm 50 \mathrm{~m}$.
Data from the grid north-western part of the Ross Ice Shelf Glaciological and Geophysical Survey (RIGGS) (Bentley and others 1979) have been incorporated into this study. There is agreement to better than $20 \mathrm{~m}$ between RIGGS and GSIRE ice-thickness data. Some of the ice-thickness data obtained from five of the NSF-SPRI-TUD radar-sounding flights during 1974-75 (Rose 1979) have also been used (Fig. 1). The relative accuracy of the ice thicknesses from those flights is better than $20 \mathrm{~m}$, but the navigational errors could be as high as $10 \mathrm{~km}$. In order to minimize these errors we have corrected the position of the flights by 
Fig. 2a. Map of the ice streams, ice rises, and grounding lines in the Siple Coast region (as in Fig. 1), together with ice-thickness contours (solid lines). Contour intervals are $50 \mathrm{~m}$ from 400 to $1000 \mathrm{~m}$ (the $380 \mathrm{~m}$ contour at grid $2^{\circ} \mathrm{W}, 8.5^{\circ} \mathrm{S}$, and $780 \mathrm{~m}$ con W, $8.5 \mathrm{~S}$, and $780 \mathrm{~m}$ contour Streand the grounding tine of 100 Stream B are also shown), $100 \mathrm{~m}$ from 1000 to $1400 \mathrm{~m}$, and $200 \mathrm{~m}$ at greater ice thicknesses. The contours along the Transantarctic Mountains and at the head of Ice Stream A are drawn at $200 \mathrm{~m}$ intervals. Surface stations of the Siple Coast Project (solid circles), RIGGS (open circles), and the IGY Ross Ice Shelf traverse (open Ross lce Shelf traverse (open squares) are shown. For radar Grout lines, refer to Figure-1. Grounding lines and ice-rise boundaries are shown by shortdashed lines. The long-dashed ines are the boundaries between confluent ice streams B1 and B2 and their associated flow bands on Ross Ice Shelf. The light shading over part of "ridge AB" represents with a poorly defined boundary.

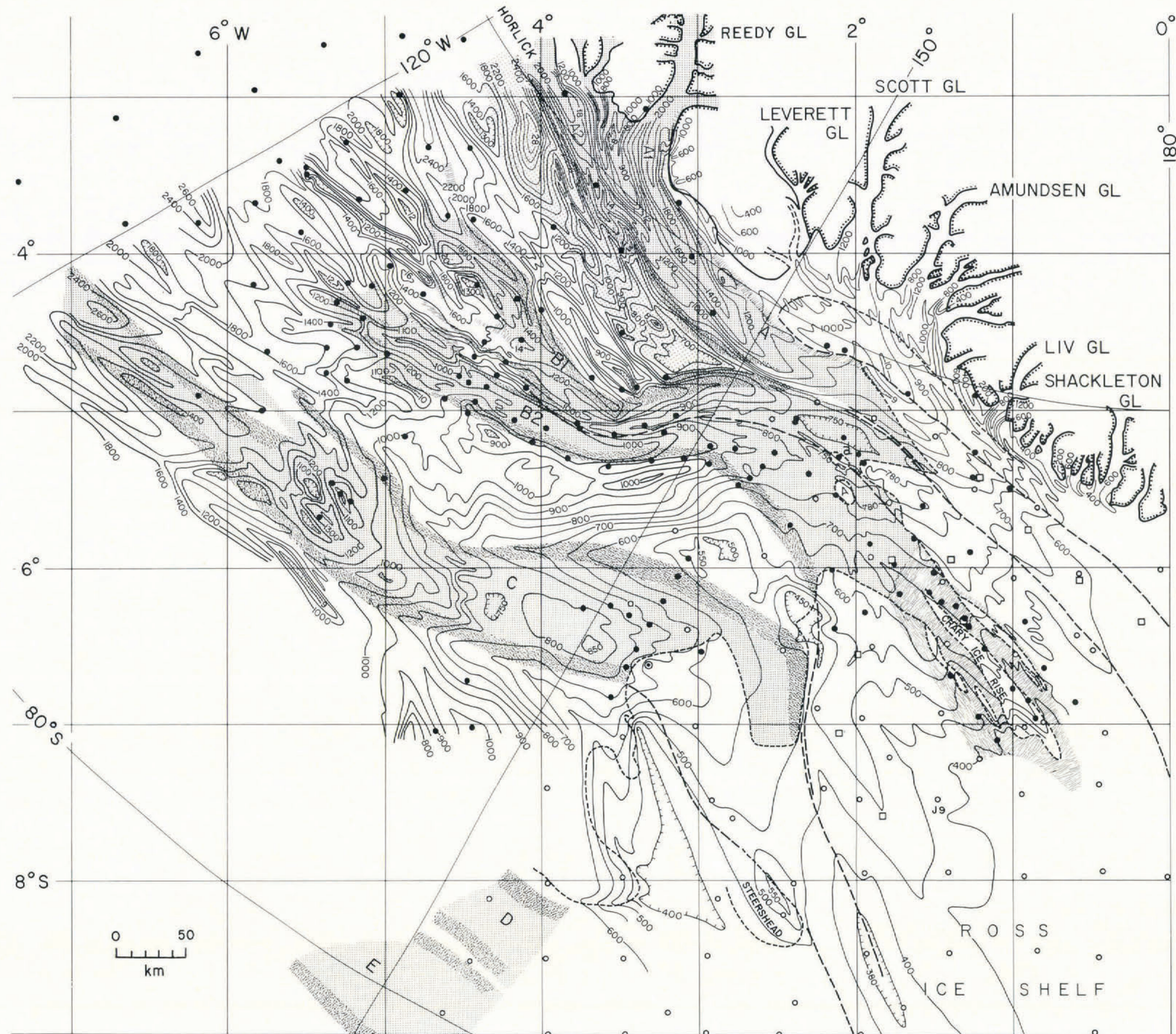

University of Wisconsin Radar Sounding Compiled by Sion Shabtaie July, 1987 


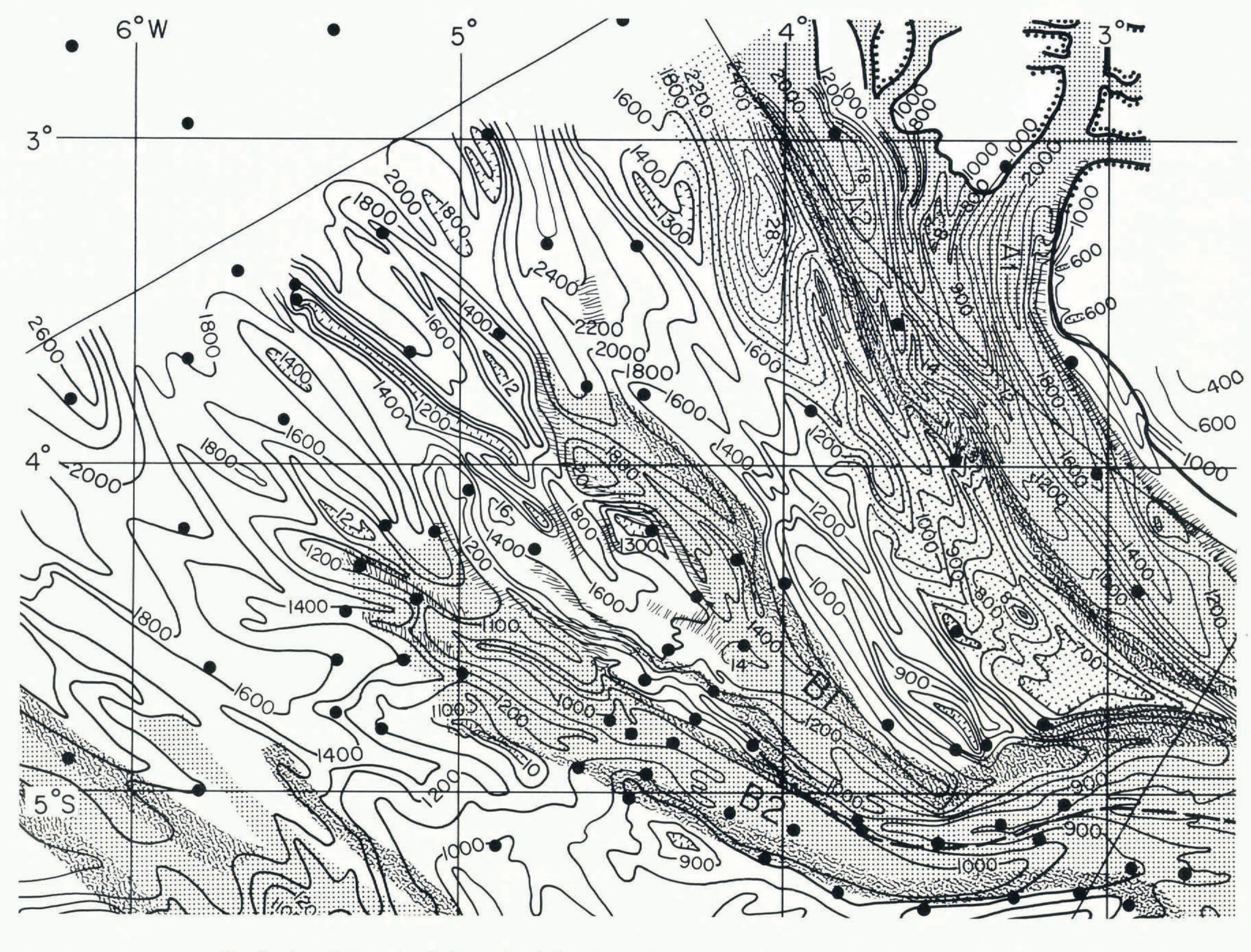




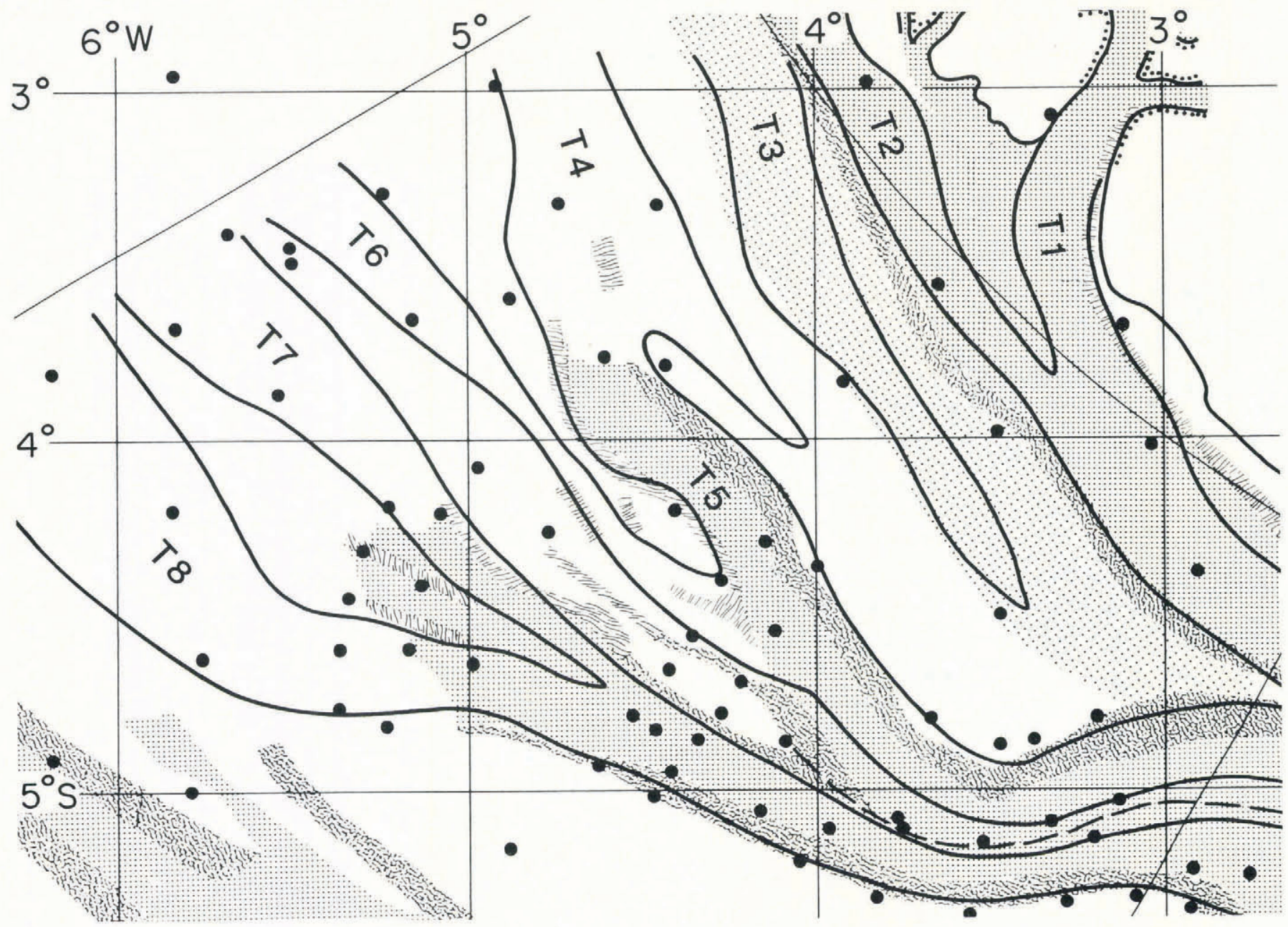

Fig. 2c. Schematic diagram showing the approximate location of subglacial troughs (i.e. T1-T7) under the ice streams.

tying them to the marginal shear-zone boundaries of the ice streams shown in Figure 1. With this correction, the agreement between the two sets of ice-thickness data is better than $\pm 50 \mathrm{~m}$. From the consistency of all the data sets we conclude that the features shown on the map (Fig. 2) are probably real, and certainly so when they are represented by more than one contour line. The contour intervals on the map are $50 \mathrm{~m}$ from 400 to $1000 \mathrm{~m}, 100 \mathrm{~m}$ from 1000 to $1400 \mathrm{~m}$, and $200 \mathrm{~m}$ at greater ice thicknesses. There are a few exceptions: along the Transantarctic Mountains and the grid north edge of Ice Stream A the contour intervals are $200 \mathrm{~m}$ because of highly variable icethickness patterns and the high density of the lines; extra contours at $780 \mathrm{~m}$ down-stream of Ice Stream B and at $380 \mathrm{~m}$ in flow band $\mathrm{C}$ are also shown.

\section{ICE-THICKNESS MAP}

The thickness map shown in Figure 2 covers ice streams A, B, and C, and much of their environs, in much more detail than previous maps (Drewry 1983). The striking feature of the map is the complexity of the ice-thickness distribution on the ice streams and the ridges.

The previously published surface-elevation map of the area (Shabtaie and others 1987) is shown in Figure 3. In future work we plan to produce a map of bedrock topography from the maps of Figures 2 and 3 ; for the present we note that variations in ice thickness must represent primarily bed topography because the surface topography is relatively subdued. We have chosen four cross-sectional profiles across the ice streams in order to show both surface and subglacial topography. The positions of the ice streams, ridges, and domes are indicated on each cross-section (Fig. 4). Most of the data for each profile were obtained along the radar-sounding flight lines (shown by solid lines in Figs 3 and 4), but there are sections of the profiles that were obtained from the contour maps of surface elevation and ice thickness in Figures 2 and 3 (shown by dashed lines in Figs 3 and 4).

A number of different subglacial troughs are referred to in the following description; for ease of reference they have been numbered $\mathrm{T} 1-\mathrm{T} 7$ on the schematic diagram of Figure 2c.

\section{ICE STREAM A}

The present configuration shows two major branches for Ice Stream A, namely ice streams A1 and A2. Ice Stream Al is marked by a pronounced subglacial trough (Tl in Fig. 2c), several hundred kilometers long, that deepens progressively up-stream and extends beneath Reedy Glacier (Figs 2 and 4). A second trough (T2), in which the ice is nearly as thick at the head end as in the Al trough, enters Ice Stream A2 from beneath Horlick Ice Stream. Ice stream A2 thins and narrows gradually down-stream, and disappears at about grid $3^{\circ} \mathrm{W}$ (Figs 2 and 4 ).

The grid western boundary of Ice Stream A (i.e. A2) between grid $3^{\circ} \mathrm{S}$ and $4^{\circ} \mathrm{S}$ has been drawn differently in Figures 2 and 3 from the way it was drawn in our previous publications (Shabtaie and Bentley 1986, 1987; Shabtaie and others 1987); for comparison, the older boundary has been kept in Figure 1. The newer, straighter boundary seems to be justified because of the corresponding boundary of the underlying trough, and because of strong radar "clutter" (energy back-scattered from open or buried crevasses) observed on a flight line running along grid $3.5^{\circ} \mathrm{S}$. However, we have no flight lines between grid $3.5^{\circ} \mathrm{S}$ and $3^{\circ} \mathrm{S}$ to provide direct evidence.

There is a subglacial highland, near the head of the ice stream between troughs $\mathrm{T} 1$ and $\mathrm{T} 2$, that rises close to 


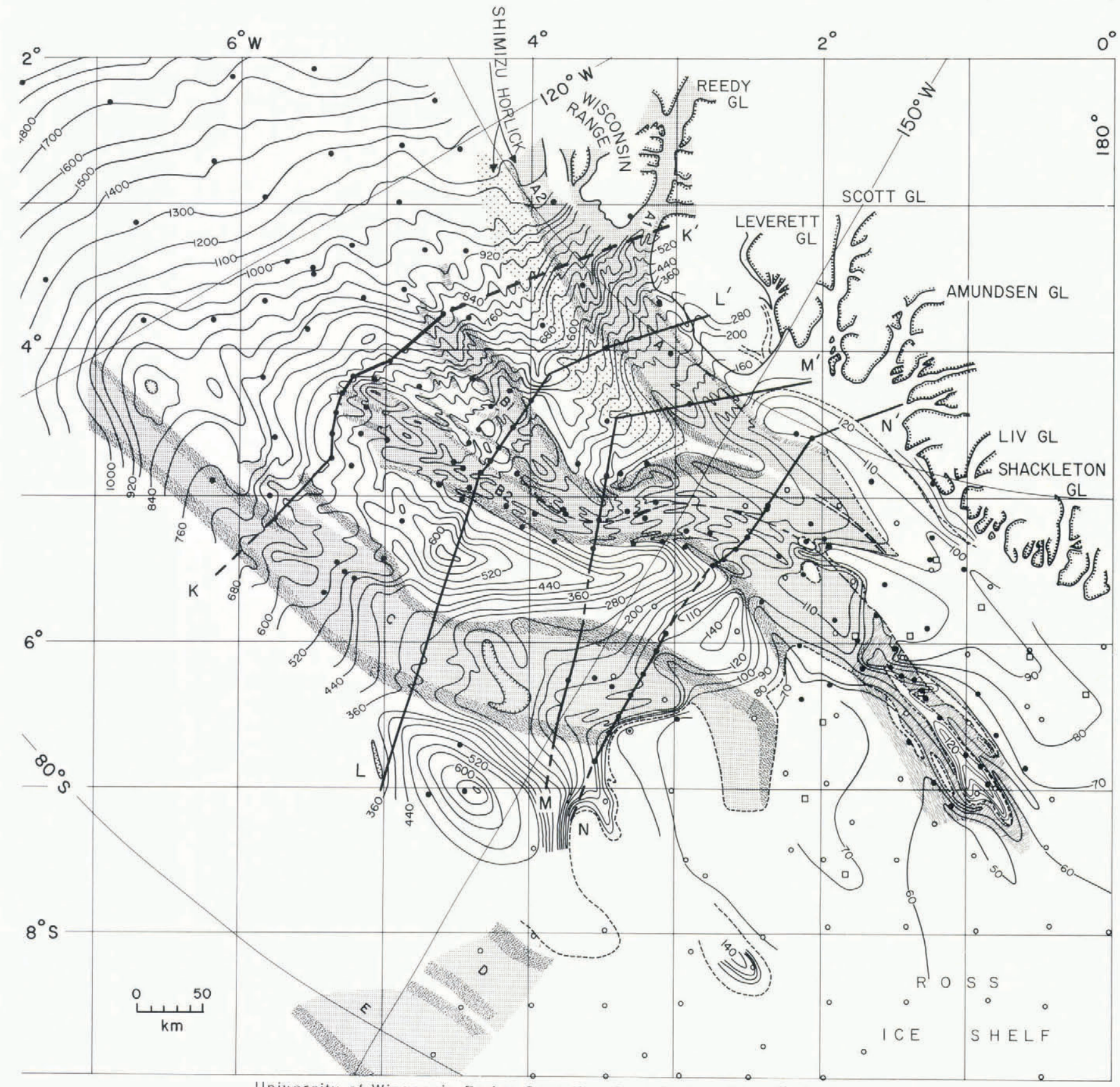

University of Wisconsin Radar Sounding Compiled by Sion Shabtaie July, 1987

Fig. 3. Map of the ice streams, ice rises, and grounding lines in the Siple Coast region (as in Fig. 1), together wth surface-elevation contours (solid lines). Contour intervals are $10 \mathrm{~m}$ from 50 to $120 \mathrm{~m}$ (the $110 \mathrm{~m}$ contour on Crary Ice Rise (identified in Figs 1 and 2a) is omitted), $20 \mathrm{~m} \mathrm{from} 120$ to $200 \mathrm{~m}$, $40 \mathrm{~m}$ from 200 to $1000 \mathrm{~m}$, and $100 \mathrm{~m}$ at higher elevations. The $1984-85$ Siple Coast Project stations of all groups (solid circles), RIGGS surface stations (open circles), and IGY Ross Ice Shelf surface-traverse stations (open squares) are shown; for radar flight lines, refer to Figure 1. Grounding lines and ice-rise boundaries shown by short-dashed lines have been taken from Shabtaie and Bentley (1987). The long-dashed lines are the boundaries between the two confluent ice streams B1 and B2 and their associated flow bands on Ross Ice Shelf. The hachured zone around and up-stream of Crary Ice Rise is intensively crevassed and locally grounded (ice rumples). The position of the cross-sections along the flight lines (heavy lines) and interpolated part using maps in Figures 2 and 3 (heavy dashed line), i.e. KK', that are shown in Figure 4, are shown. The light shading over part of "ridge AB" represents a suggested remanant ice stream with a poorly defined boundary.

sea-level beneath the thin-ice area (Fig. 4a), and is incised by relatively deep channels that connect to the valley glaciers in the Wisconsin Range. This highland diminishes in height and width down the ice stream until it disappears at about grid $4{ }^{\circ} \mathrm{S}$. Correspondingly, troughs $\mathrm{T} 1$ and $\mathrm{T} 2$ are deepest at their head ends and gradually shoal toward the grounding line. Thus the transverse ice-thickness variation within Ice Stream A diminishes from $1500 \mathrm{~m}$ at its head to only $200 \mathrm{~m}$ at its mouth.

The grid south-western margin of Ice Stream A overlies the top of a steep subglacial slope throughout its length (Figs 2 and 4). In contrast, the grid north-eastern margin of ice stream Al gradually moves over deeper and deeper ice as it recedes $10-25 \mathrm{~km}$ from the mountain front (Figs 2 and $4 \mathrm{a}$, and 2 and $4 \mathrm{~b}$ ), so that the ice stream no longer overlies the entire subglacial trough. 


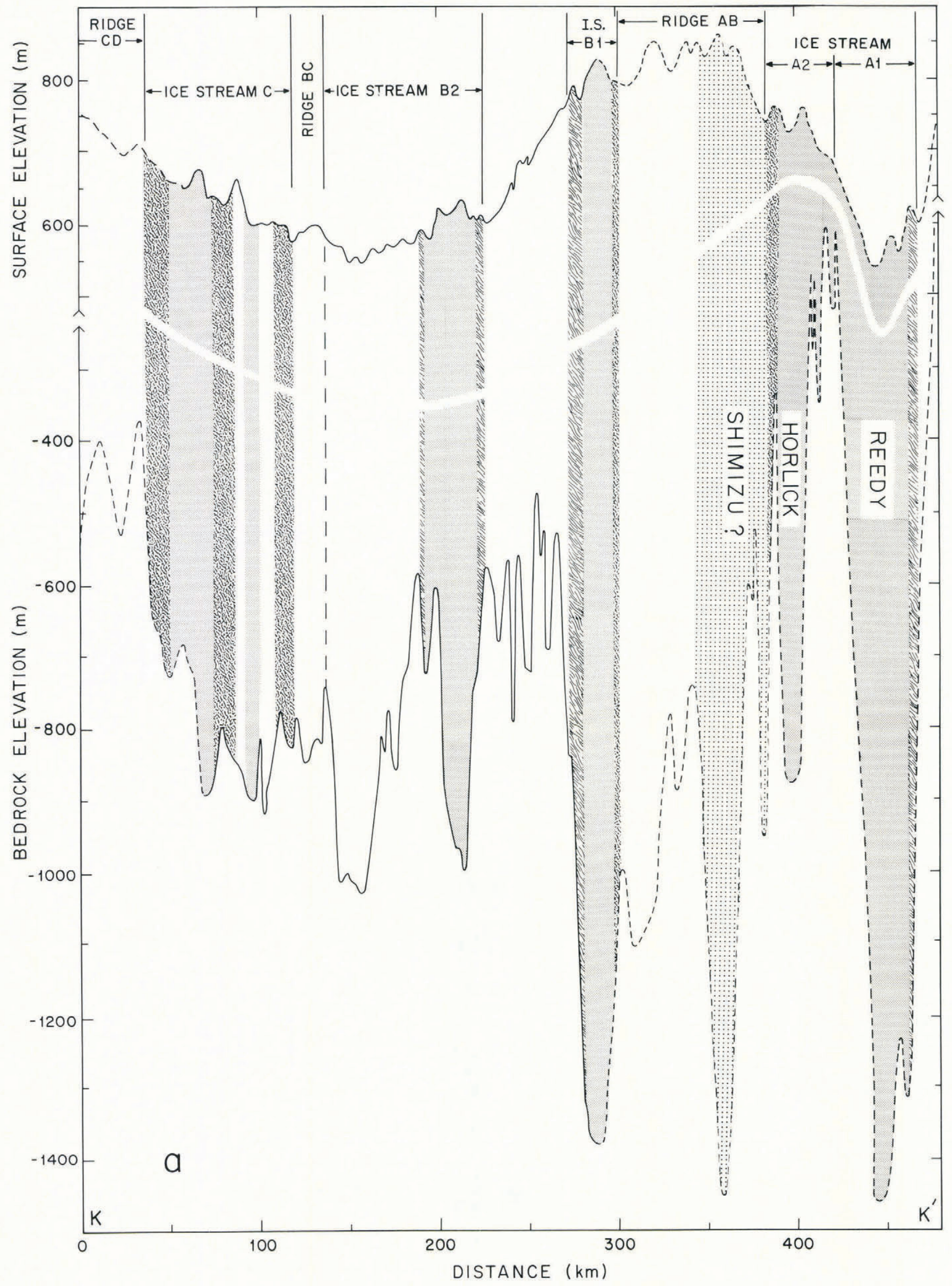

Fig. 4a

Figs $4 a-d$. Cross-sections along the lines indicated in Figure 3. The heavy shading denotes the marginal shear zone of the ice stream; the light shading denotes the less chaotic main body of the ice stream. The surface and bedrock profiles along the flight lines are shown by solid lines, and the interpolated parts using maps in Figures 2 and 3 are shown by dashed lines. 


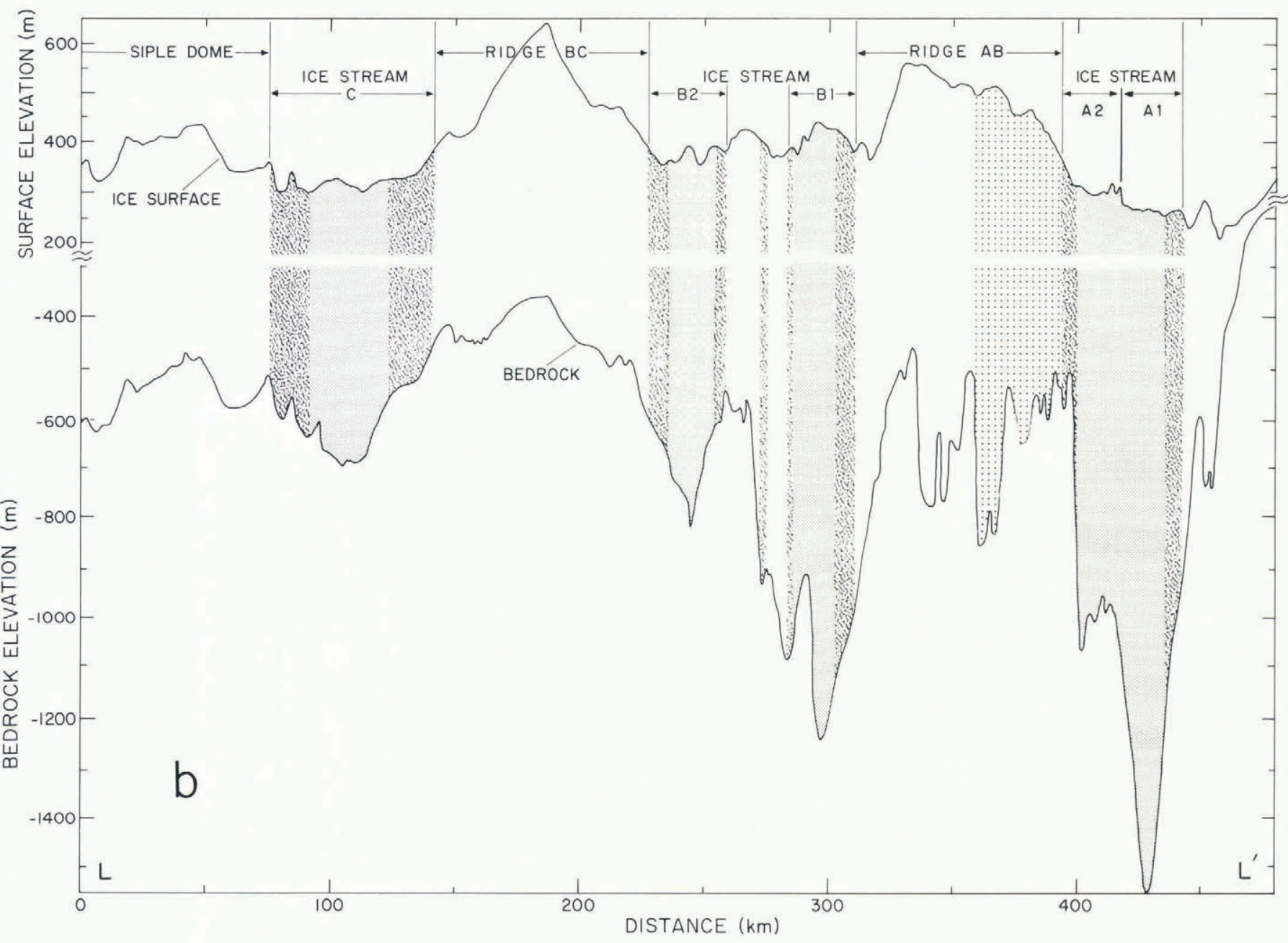

Fig. 4b

\section{Ridge $\mathbf{A B}$}

There is a prominent, thick lobe of ice that trends into ridge $\mathrm{AB}$ adjacent to Ice Stream $\mathrm{A} 2$ and separated from it by a linear subglacial ridge (Figs 2 and 4a). This lobe is associated with a subglacial trough (T3) that is even deeper $\left(1900 \mathrm{~m}\right.$ below sea-level at $\left.3.3^{\circ} \mathrm{S}, 4.1^{\circ} \mathrm{W}\right)$ than those beneath ice streams $A 1$ and $A 2$ We suggest that much of the ice from Shimizu Ice Stream actually flows into ridge $A B$ along this trough, rather than flowing into Horlick Ice Stream, as it appears to do on the U.S. Geological Survey map of the area (USGS 1972), which is based on aerial-reconnaissance photography (cf. also Drewry 1978, Rose 1982). Alternatively, it is possible that this ice originates not from Shimizu Ice Stream, but from another unknown ice stream between the Ohio and Wisconsin ranges.

There is also weak radar clutter associated with this thick ice lobe that can be traced on all of the flight lines crossing this area. The clutter is much weaker even than that from inactive Ice Stream C, but, as on Ice Stream C (Shabtaie and Bentley 1987), it is stronger up-stream than down-stream. In a separate paper we will develop a thesis that this band is a remanent ice stream.

The ice-thickness map (Fig. 2) shows another prominent lobe of thick ice extending into ridge $\mathrm{AB}$ at about $4.8^{\circ} \mathrm{W}$ from a wide, deep trough (T4) in central West Antarctica (Drewry 1983) that also connects with Ice Stream B1. Farther down-ridge, both the ice-thickness and surface-elevation maps show strong relief. This association of an irregular surface with an irregular bed strongly suggests that ridge $\mathrm{AB}$ is dynamically much more active than Siple Dome or ridge BC.

\section{ICE STREAM B}

The head of Ice Stream B1 is characterized by a deep subglacial trough (T5) (ice thickness $>2000 \mathrm{~m}$ ) that connects with the central West Antarctic trough (T4) referred to above. Trough T5 continues beneath Ice Stream B all the way to the ice plain, disappearing near grid $2.5^{\circ} \mathrm{W}$. Surprisingly, it is centered more nearly under the grid northern shear margin of Ice Stream B than beneath its axis. A second trough (T6), shallower and more irregular (it can be distinguished in Fig. $4 \mathrm{~b}$ but not in $4 \mathrm{a}$ ), runs from grid $3.4^{\circ} \mathrm{S}, 5.3^{\circ} \mathrm{W}$ axially along ridge $\mathrm{B} 1 / \mathrm{B} 2$ between ice streams B1 and B2, and thence into Ice Stream B1, merging with the main trough at about $4.7^{\circ} \mathrm{S}, 4.2^{\circ} \mathrm{W}$. Like Ice Stream A, Ice Stream Bl diminishes markedly in thickness down-stream (Fig. 4).

Ice Stream B2 has three branches at its head, separated by bands of intense clutter (the three branches can be seen most clearly in Fig. 3). The surface (Fig. 4) is higher on the middle branch than on the others. This surface high overlies an elongated subglacial ridge, whereas subglacial troughs (T7 and T8) underlie the branches on each side. Unlike ice streams A and B1, Ice Stream B2 has a nearly constant ice thickness from grid $5^{\circ} \mathrm{W}$, near its head, to grid $3^{\circ} \mathrm{W}, 250 \mathrm{~km}$ down-stream. There is a rather poorly defined subglacial ridge running along (just outside) its grid south-western margin. The boundary between ice streams B1 and B2 overlies a linear subglacial ridge that extends from the ice plain to the "peninsula" between the two tributaries where they converge; farther up-stream it marks the boundary between ridge B1/B2 and Ice Stream B2.

Ridge $\mathrm{B} 1 / \mathrm{B} 2$ is a complex zone containing several "islands" of clutter-free ice, typical of the slow-moving ice ridges and domes, separated by disturbed ice zones (Figs 1, 2 , and 3 ). The clutter-free "islands" are marked by several closed minima and maxima in ice thickness. This zone is also characterized by a complex pattern of surface elevation with closed maxima. The complex distribution of crevasses, the surface topography, and a strong negative mass-balance calculation for the adjacent parts of ice streams B1 and B2, all suggest that parts of ridge $\mathrm{B} 1 / \mathrm{B} 2$ are dynamically 


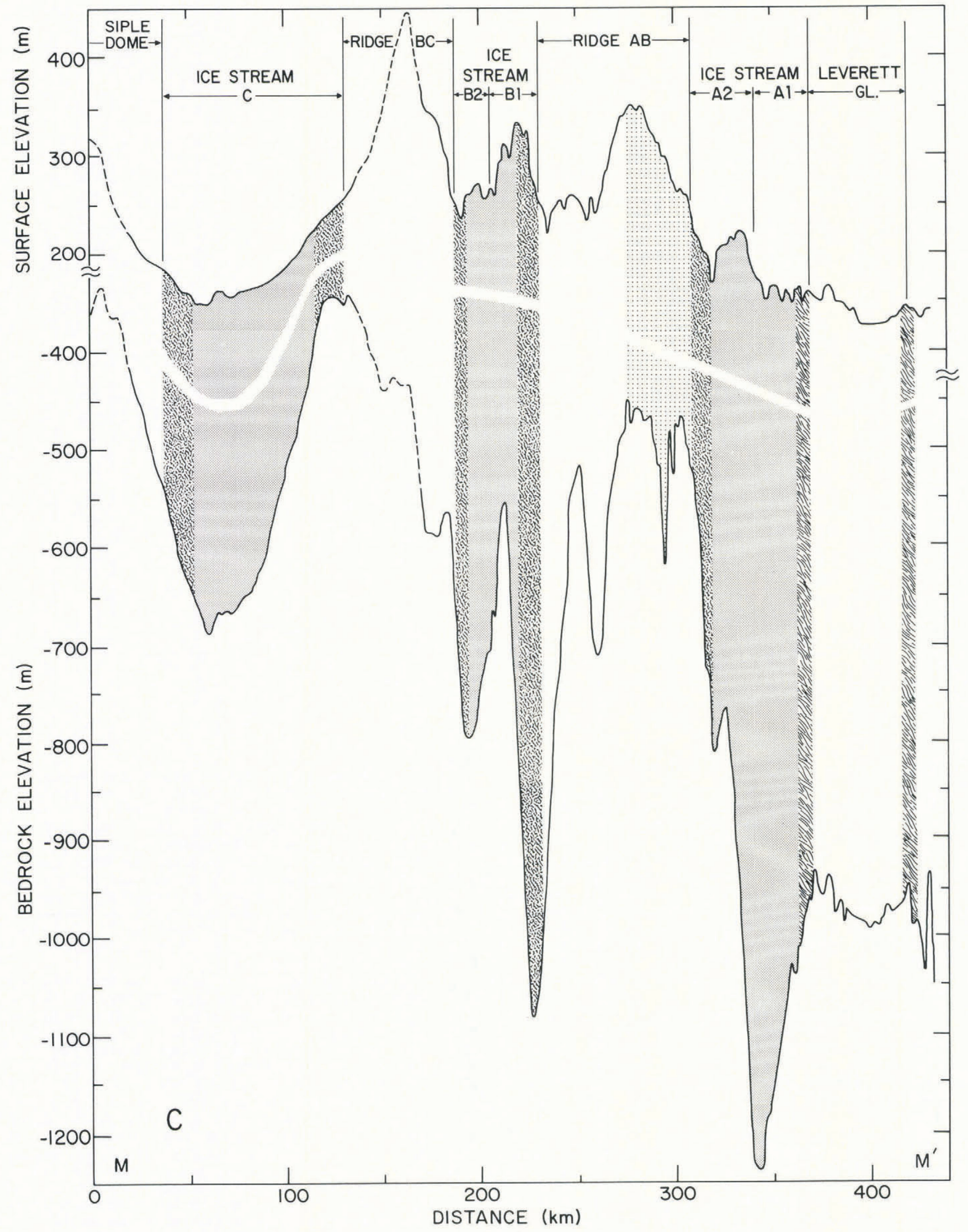

Fig. 4c

unstable and are in the process of being added to the ice streams (Shabtaie and Bentley 1987, Shabtaie and others 1987, Shabtaie and others 1988, this volume).

The fact that there is poor correlation between the grid north-eastern marginal shear zone of Ice Stream B and the subglacial topography (Figs 2 and 4) suggests that the position of that boundary may not be stable. The lateral expansion of Ice Stream B near its head has already been proposed by Shabtaie and others (1988, this volume). Perhaps lateral movement is also occurring elsewhere along the ridge $A B$ side of Ice Stream $B$, where multiple marginal shear zones are observed and the adjacent surface elevations on ridge $\mathrm{AB}$ are lower than those on Ice Stream B (Figs 3 and 4). 


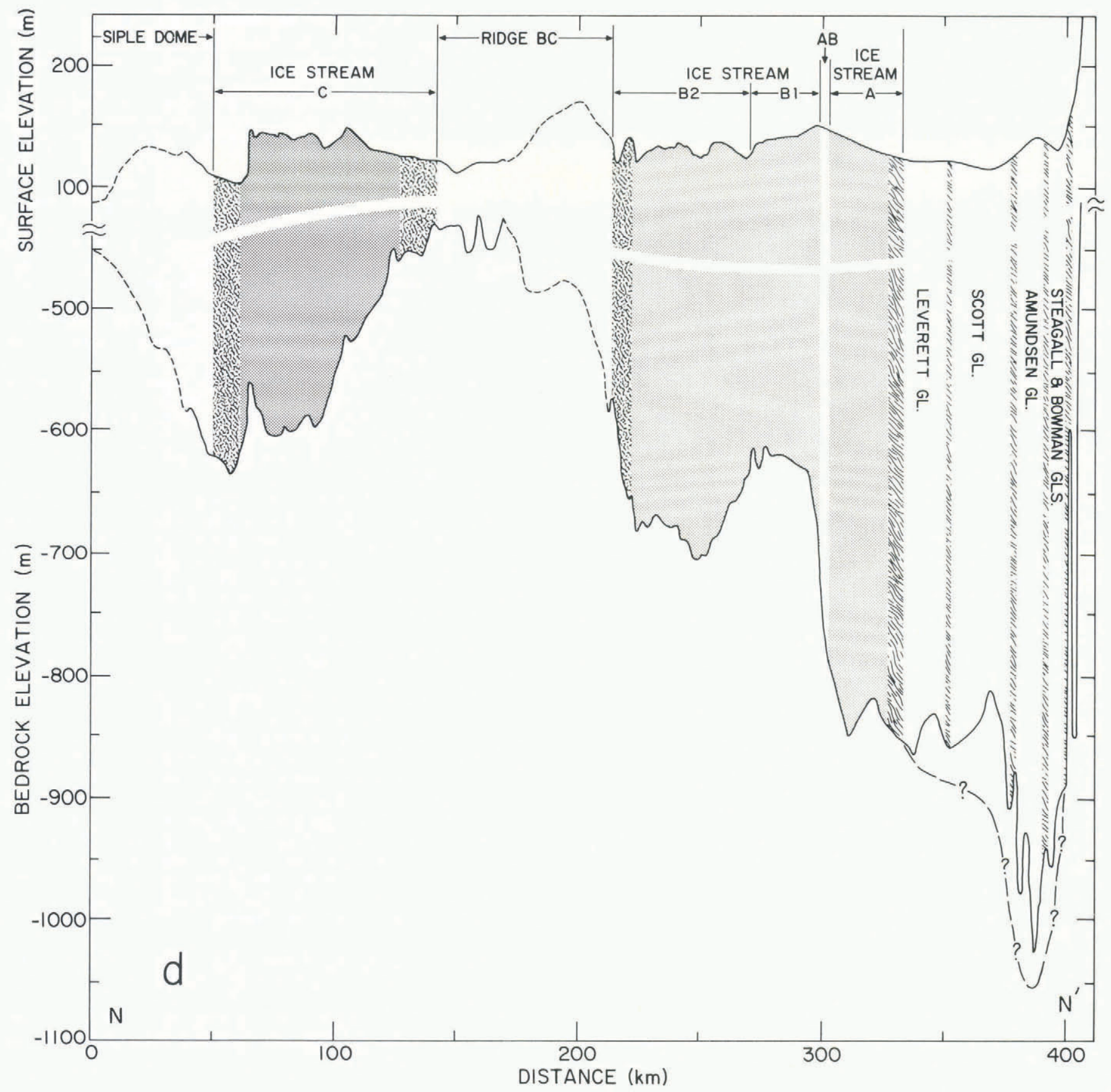

Fig. 4d

\section{Ridge $\mathrm{BC}$}

$\mathrm{By}$ comparison with ridge $\mathrm{AB}$ and ridge $\mathrm{B} 1 / \mathrm{B} 2$, ridge BC shows a smooth pattern of ice-thickness variation. Between grid $4^{\circ} \mathrm{W}$ and $5^{\circ} \mathrm{W}$ there is a subglacial high that correlates with the surface dome (Fig. 4b), but farther down-stream there is not (Fig. 4c and d). The bed of the ridge is moderately dissected grid west of $4^{\circ} \mathrm{W}$, but there is little reflection of that in the surface topography. The small subsidiary dome near grid $6^{\circ} \mathrm{S}, 2.7^{\circ} \mathrm{W}$ appears to be associated with, but displaced grid eastward from, an ice-thickness minimum (bed high).

\section{ICE STREAM C}

Inactive Ice Stream $\mathrm{C}$ differs from active ice streams $\mathrm{A}$ and $B$ in that there are several closed maxima and minima in surface-elevation and ice-thickness contours. Surface features are poorly correlated with ice thickness. For example, the most prominent surface depression, around grid $4.2^{\circ} \mathrm{W}$ (Fig. 3), does not correspond well to either a minimum or maximum in ice thickness, although there is a smaller minimum slightly to the grid west. Two other surface depressions that are too shallow to show in Figure 3 (they show up with a $20 \mathrm{~m}$ contour interval), located at grid $5.8^{\circ} \mathrm{S}, \quad 5^{\circ} \mathrm{W}$ (elevation $375 \mathrm{~m}$ ) and grid $5.5^{\circ} \mathrm{S}, \quad 5.8^{\circ} \mathrm{W}$ (elevation $565 \mathrm{~m}$ ), similarly do not occur on ice-thickness extrema. On average, the bed of the ice stream lies at a nearly constant elevation, between 600 and $900 \mathrm{~m}$ below sea-level (Fig. 4). In this respect it is much more like Ice Stream B2 than like ice streams B1 or A. The marginal shear zones of the ice stream generally lie on the flanks of subglacial ridges, but, like the other ice streams, Ice Stream $\mathrm{C}$ is commonly disposed asymmetrically with respect to the valley in which it lies (Fig. 4c and d).

There is a wide, but relatively flat, lobe of sluggish ice extending toward the ice shelf at the grounding line. This lobe of ice thins and narrows rapidly, and completely disappears as the ice moves toward Steershead Ice Rise. The extreme thinning and narrowing of flow band $\mathrm{C}$ is presumably a response to the stagnation of Ice Stream C (Shabtaie and Bentley 1987).

In general, this ice stream has more subglacial irregularities than other ice streams. Whether the local subglacial rises (the closed minima in ice-thickness contours) play a role in ice-stream stagnation is unknown, but calculation shows (Shabtaie and Bentley 1987) that in some areas they do help to cause reversed hydraulic potential gradients, which divert the subglacial water up-glacier, although it is principally the reversed surface slopes (Fig. 3) that are responsible. 


\section{CONCLUSION}

The subglacial topography of the ice stream $\mathrm{A}-\mathrm{B}-\mathrm{C}$ region is complex. The ice-thickness variations that are associated with the basal topography strike parallel and along the ice-stream flow. This pattern of ice-thickness variation suggests a strong bed molding by ice flow, with a more erosive action concentrated in the basal troughs of the ice stream. Subglacial slopes of 0.05 are common in the interior part of the region. The relief is much more subdued along the coastal region next to Ross Ice Shelf, particularly away from the Transantarctic Mountains front, along which there is a deep trench reaching more than a kilometer below sea-level. The ice streams are associated with subglacial troughs, but in many places (i.e. Ice Stream B) are placed asymmetrically over those troughs.

There are about ten deep troughs inland; they converge into and along the ice streams, so that near the grounding line there are only four, one each beneath ice streams A, $\mathrm{B} 1, \mathrm{~B} 2$, and $\mathrm{C}$. One striking feature of these troughs is that they are increasingly deep toward the Transantarctic Mountains, but they all shoal down-stream toward the grounding lines.

There is no step in either the bed topography (abruptly deeper down-stream) or the surface topography (abruptly lower down-stream), such as has been observed for a few outlet glaciers (McIntyre 1985), at the head of any of the ice streams discussed here. On the contrary, in the zone in which the flow lines show a strong lateral convergence, which starts at the head of ice streams B and C and continues about $100 \mathrm{~km}$ up-stream, the ice thins by as much as $1000 \mathrm{~m}$ in less than $100 \mathrm{~km}$. This may reflect the relative impermanence of these features, compared with outlet glaciers whose positions are fixed by rock walls.

\section{ACKNOWLEDGEMENTS}

The authors are grateful to their co-workers at the University of Wisconsin-Madison for field assistance, and to their colleagues I.M. Whillans, R.A. Bindschadler, S.N. Stephenson, and D.R. MacAyeal for ground-control information and many informative discussions. This work was supported by U.S. National Science Foundation grant DPP84-12404. This is contribution No. 482 of the University of Wisconsin-Madison, Geophysical and Polar Research Center.

\section{REFERENCES}

Bentley, C.R., J.W. Clough, K.C. Jezek, and S. Shabtaie. 1979. Ice-thickness patterns and the dynamics of the Ross Ice Shelf, Antarctica. J. Glaciol., 24(90), 287-294.
Bindschadler, R.A., S.N. Stephenson, D.R. MacAyeal, and S. Shabtaie. 1987a. Ice dynamics at the mouth of Ice Stream B, Antarctica. J. Geophys. Res., 92(B9), 8885-8894.

Bindschadler, R.A., D.R. MacAyeal, and S.N. Stephenson. 1987b. Ice stream-ice shelf interaction in West Antarctica. In Veen, C.J. van der, and J. Oerlemans, eds. Dynamics of the West Antarctic Ice Sheet. Proceedings of a Workshop held in Utrecht, May 6-8, 1985. Dordrecht, etc., D. Reidel Publishing Company, 161-180.

Drewry, D.J. 1978. Aspects of the early evolution of West Antarctic ice. In Zinderen Bakker, E.M. van, $s r$, ed. Antarctic glacial history and world palaeoenvironments. Rotterdam, A.A. Balkema, 25-32.

Drewry, D.J. 1983. Antarctica: glaciological and geophysical folio. Cambridge, University of Cambridge. Scott Polar Research Institute.

Hughes, T.J. 1973. Is the West Antarctic ice sheet disintegrating? J. Geophys. Res., 78(33), 7884-7910.

McIntyre, N.F. 1985. The dynamics of ice-sheet outlets. J. Glaciol., 31(108), 99-107.

Robin, G. de Q. 1975. Ice shelves and ice flow. Nature, 253(5488), 168-172.

Robin, G. de Q., S. Evans, D.J. Drewry, C.H. Harrison, and D.L. Petrie. 1970. Radio-echo sounding of the Antarctic ice sheet. Antarct. J. U.S., 5(6), 229-232.

Rose, K.E. 1979. Characteristics of ice flow in Marie Byrd Land, Antarctica. J. Glaciol., 24(90), 63-75.

Rose, K.E. 1982. Radio-echo studies of bedrock in southern Marie Byrd Land, West Antarctica. In Craddock, C., ed. Antarctic geoscience. Madison, WI, University of Wisconsin Press, 985-992.

Shabtaie, S., and C.R. Bentley. 1986. Ice streams and grounding zones of West Antarctica and the Ross Ice Shelf. (Abstract.) Ann. Glaciol., 8, 199-200.

Shabtaie, S., and C.R. Bentley. 1987. West Antarctic ice streams draining into the Ross Ice Shelf: configuration and mass balance. J. Geophys. Res., 92(B2), 1311-1336.

Shabtaie, S., I.M. Whillans, and C.R. Bentley. 1987. The morphology of ice streams A, B, and C, West Antarctica, and their environs. J. Geophys. Res., 92(B9), 8865-8883.

Shabtaie, S., C.R. Bentley, R.A. Bindschadler, and D.R. MacAyeal. 1988. Mass-balance studies of ice streams $\mathrm{A}, \mathrm{B}$, and $\mathrm{C}$, West Antarctica, and possible surging behavior of Ice Stream B. Ann. Glaciol., 11, 137-149.

United States Geological Survey. 1972. Ross Ice Shelf map. Scale 1:1,000,000. Reston, VA, United States Geological Survey.

Whillans, I.M., J. Bolzan, and S. Shabtaie. 1987. Velocity of ice streams B and C, Antarctica. J. Geophys. Res., 92(B9), 8895-8902. 